\title{
Gender Divide in Provision of Extension Services in Agriculture
}

\author{
Mani Bhushan ${ }^{1}$, Aditya Sinha ${ }^{2 *}$, SaritaKumari $^{3}$ and Dharmendra Debbarma ${ }^{4}$
}

${ }^{1}$ Bhola Paswan Shastri Agricultural College, Purnea-854 302 Bihar, India

${ }^{2}$ Bihar Agricultural College, Sabour-813 210 Bhagalpur Bihar, India

${ }^{3}$ College of Community \& applied sciences, MPUA\&T, Udaipur-313 001, Rajasthan, India

${ }^{4}$ Department of Agril. Extension College of Agriculture Tripura, Lembucherra-799210, India

*Corresponding author

\section{A B S T R A C T}

The role of women farmers in agricultural production has long been

\section{Keywords}

Gender,

Constraints,

Development,

Policy, Bihar

Article Info

Accepted:

12 March 2020

Available Online:

10 April 2020 debated while their role continues to remain largely unrecognized by the extension machinery of the state and developmental programmes. The present study is aimed at studying the gender division of labour in agricultural production with reference to three villages in rural Purnea district of Bihar. The impact of liberalization and globalization on women is important in the current decade not only because they represent almost half of the total population, but also because they face constraints, which make them less beneficial from the liberalization. The assessments of developmental goals in relation to gender division of farmers for designing better policy implications as well as minimizing the effect of quantitative targeting of clients and developing policies and programs that strengthen women's physical access to resources remain important.

\section{Introduction}

The development community across the globe has recognized the importance of agriculture in poverty alleviation with special reference to women farmers who make essential contributions to the agricultural and rural economies in all developing countries. Rapid globalization and changing times are aiding in a considerable variation in the traditional roles played by the women in transforming the agricultural sector. The activities of the rural women typically include producing agricultural crops, tending animals, processing and preparing food, working for wages in agricultural or other rural enterprises, collecting fuel and water, engaging in trade and marketing, caring for family members and maintaining their homes (FAO, 2011). 
The activities mentioned above are not mainly categorized under "economically active employment" but are of utmost importance for the growth of the rural households.

The FAO (2011) report upholds that women farmers comprise on an average, 43 per cent of the agricultural labour force in developing countries, ranging from 20 per cent in Latin America to 50 per cent in Eastern Asia and Sub-Saharan Africa. The report also underlines that reducing gender inequalities in access to productive resources and services could produce an increase in yields on female's farms of between 20 per cent and 30 per cent, which could raise agricultural output in developing countries by 2.5 per cent to 4 per cent. It becomes evident that it calls for an equal attention for both male and female farmers for increasing the potential of agriculture and allied sector. It further calls for better access to information and assistance by the extension machinery.

The underlying problems with the extension machinery in the developing countries behold that women farmers are not actually considered as decision makers in the real sense. It has been observed that the extension strategies have typically focussed on increasing production of cash crops by providing men with training, information, and access to inputs and services in the past. This male bias can often be observed by following farmer training centres in the developing countries in which only a few courses is available for the women farmer while most of the courses are designed for men for meeting the residential training requirements.

The female farmers daily workloads usually do not allow them to be absent for such training along with difficulties in the provision of proper accommodation. It has also been observed that even where attendance of women is quite high as a proportion of the total, women are mainly instructed in subjects like home sciences and crafts with the exclusion of technical expertise in agriculture and allied domains (Staudt, 1973; Perraton et al., 1983).

The government has come up with many policy initiatives to promote entrepreneurship and growth in all sectors of the economy with special importance on the agricultural sector since the economic liberalization in 1991. The government has also come up with several relaxations for women to facilitate the participation of women beneficiaries in various schemes. The government is currently operating over 27 schemes for women through different departments and ministries.

Some of these are Integrated Rural Development Programme (IRDP), Khadi And Village Industries Commission (KVIC), Training of Rural Youth for Self-Employment (TRYSEM), Prime Minister's RojgarYojana (PMRY), Entrepreneurial Development programme (EDPs), Management Development progammes, Womens Development Corporations (WDCs), Marketing of Non-Farm Products of Rural Women (MAHIMA), NGOs Credit Schemes, Micro \& Small Enterprises Cluster Development Programmes (MSE-CDP) amongst others (ET contributors, 2017). Along with it, several Non-governmental organizations (NGO) are exclusively working for women in several specialized areas for developing capabilities in women farmers for inclusive development over the recent years.

\section{Materials and Methods}

The data used in this study were collected from household surveys conducted in three selected villages of Purnea by the students engaged in Rural Agricultural Work Experience (RAWE) program during September and October 2019. Multi stage 
sampling procedure was used to select the villages and farm households. In the first stage, Purnea district was selected purposively for satisfying the following criteria; where mixed farming (crop and livestock) is widely practiced, where extension program have been implemented for relatively longer period of time, the availability of different agro-climatic scenario along with suitability in the context of Bihar state.

The three villages were randomly selected from each of the blocks in Jalalgarh, Kasba and Rupauliout of the total 164 villages found in the district. Further, stratified random sampling technique was employed to select a total of 150 farm households (110 men and 40 women). Sample farmers were identified from a list made available by the website of the election commission which was further confirmed by the farmers and extension workers of the region.

The data collection was performed using structured and pre-tested questionnaire. Interviews and focus group discussions were also used to further substantiate the database. The extent of gender role in agricultural activities were measured by using a five point continuum namely 'Never', 'Rarely', 'Sometimes', 'Often', and 'All of the Time'. The descriptive statistics, $t$ test and chi-square tests were also used to understand the gender division in farming.

\section{Results and Discussion}

The average age of the farmers in the study area was 45.70 while the experience in farming attributed to 10.72 . It can be observed from the table 1 and 2 that there is a significant difference between male and female heads across a number of dimensions. The female heads are on the average with low levels of education combined with smaller family size and labour force in terms of adult equivalent scale.

The female households look in a disadvantaged position with reference to the parameters like ownership of livestock, availing credit facility, training and leadership position in the society. The female households are better off only in membership to SHG and farmers club in the region.

It can be seen in Table 3 that majority of activities like planting, weeding, fertilizer application, pesticide application, harvesting, threshing, production storage, livestock shade construction, livestock feeding, shade cleaning, dung processing, milking and milk processing, herding and poultry/goat production are carried out by the female in the study area. The male farmers are involved in activities like marketing, livestock selling and ploughing through tractor. Similar figures were observed by Elias, Asres et al., (2014).

The time budget analysis (Table 4) indicates that females spent majority of the time for domestic and farm activities compared to males. The time devoted to activities like cooking and related activities form the crux of their work. The women also play a major role in activities like kitchen gardening and management of poultry and livestock.

The constraints in relation to accessing better extension service were identified. It was found that the low exposure provided to female farmers since inception formed a major constraint along with attitude of extension systems in not reaching the women farmers effectively, less family labour, low levels of education, fragmented land holdings, lack of credit availability, and excess workload respectively. 
Table.1 Socio-economic characteristics of the respondents

\begin{tabular}{|c|c|c|c|}
\hline Variable & Frequency & Percentage & Mean \\
\hline \multicolumn{4}{|l|}{ Gender } \\
\hline Male & 110 & 73.33 & \\
\hline Female & 40 & 26.66 & \\
\hline \multicolumn{4}{|l|}{ Age (years) } \\
\hline $16-25$ & 4 & 2.66 & \\
\hline $26-35$ & 22 & 14.66 & \\
\hline $36-45$ & 58 & 38.66 & 45.70 \\
\hline $46-55$ & 39 & 26.00 & \\
\hline $56-65$ & 12 & 8.00 & \\
\hline $66-75$ & 15 & 10.00 & \\
\hline \multicolumn{4}{|l|}{ Marital status } \\
\hline Single & 16 & 10.66 & \\
\hline Married & 128 & 85.33 & \\
\hline Divorced & 2 & 1.33 & \\
\hline Widowed & 4 & 2.66 & \\
\hline \multicolumn{4}{|l|}{ Educational level } \\
\hline Primary education & 45 & 30.00 & \\
\hline Secondary education & 88 & 58.66 & \\
\hline Graduate & 10 & 6.66 & \\
\hline Post graduate & 7 & 4.66 & \\
\hline \multicolumn{4}{|l|}{ Farming experience } \\
\hline $1-5$ & 31 & 20.66 & \\
\hline $6-10$ & 45 & 30.00 & \\
\hline 11-15 & 48 & 32.00 & 10.72 \\
\hline $16-20$ & 12 & 8.00 & \\
\hline $20-25$ & 14 & 9.33 & \\
\hline
\end{tabular}


Table.2 Mean difference test of demographic characteristics, access to human, physical, capital and social resources by gender of household head

\begin{tabular}{|c|c|c|c|c|c|}
\hline \multirow[t]{2}{*}{ Resources } & \multicolumn{2}{|c|}{ Mean } & \multicolumn{2}{|c|}{ Std.dev } & \multirow{2}{*}{$\begin{array}{c}\text { P- } \\
\text { value }\end{array}$} \\
\hline & Male & Female & Male & Female & \\
\hline $\begin{array}{l}\text { Age of head of } \\
\text { family }\end{array}$ & 42.2 & 48.6 & 9.68 & 6.71 & NS \\
\hline $\begin{array}{l}\text { Education of head of } \\
\text { family (1=literate) }\end{array}$ & 0.63 & 0.27 & 0.48 & 0.34 & $* * *$ \\
\hline $\begin{array}{l}\text { Number of educated } \\
\text { family members }\end{array}$ & 4.62 & 1.89 & 1.74 & 0.86 & $* * *$ \\
\hline Family size & 4.97 & 4.22 & 1.66 & 1.12 & $* * *$ \\
\hline $\begin{array}{l}\text { Active family labour } \\
\text { in adult equivalent }\end{array}$ & 3.68 & 2.14 & 1.08 & 1.14 & $* * *$ \\
\hline Land size in hectare & 0.98 & 0.61 & 0.74 & 0.28 & $* * *$ \\
\hline Livestock ownership & 6.24 & 2.68 & 3.17 & 1.42 & $* * *$ \\
\hline $\begin{array}{l}\text { Credit availed }(1= \\
\text { Yes) }\end{array}$ & 0.26 & 0.01 & 0.24 & 0.12 & $* * *$ \\
\hline $\begin{array}{l}\text { Training availed }(1= \\
\text { Yes) }\end{array}$ & 0.92 & 0.34 & 0.48 & 0.42 & $* * *$ \\
\hline $\begin{array}{l}\text { Leadership position } \\
(1=\text { Yes })\end{array}$ & 0.26 & 0.01 & 0.42 & 0.11 & $* * *$ \\
\hline $\begin{array}{l}\text { Membership in } \\
\text { cooperatives }\end{array}$ & 0.91 & 0.36 & 0.02 & 0.06 & $* * *$ \\
\hline $\begin{array}{l}\text { Membership in } \\
\text { SHG/Farmers club }\end{array}$ & 0.38 & 0.66 & 0.08 & 0.04 & $* * *$ \\
\hline $\begin{array}{l}\text { Frequency of visit to } \\
\text { extension agent }\end{array}$ & 0.28 & 0.01 & 0.18 & 0.08 & $* * *$ \\
\hline
\end{tabular}

Source: Field Survey data, 2019-20

Table.3 Gender role for crop production and animal husbandry in the three rural villages during the main agricultural season

\begin{tabular}{|c|c|c|c|c|c|c|c|c|c|c|}
\hline \multirow[t]{4}{*}{ Activities } & \multicolumn{10}{|c|}{ Frequency of doing crop production activities } \\
\hline & \multicolumn{2}{|c|}{ Never } & \multicolumn{2}{|c|}{ Rarely } & \multicolumn{2}{|c|}{ Sometimes } & \multicolumn{2}{|c|}{ Often } & \multicolumn{2}{|c|}{ All of the time } \\
\hline & Male & Female & Male & Female & Male & Female & Male & Female & Male & Female \\
\hline & No. $(\%)$ & $\begin{array}{l}\text { No. } \\
(\%)\end{array}$ & $\begin{array}{l}\text { No. } \\
(\%)\end{array}$ & $\begin{array}{l}\text { No. } \\
(\%)\end{array}$ & No. $(\%)$ & $\begin{array}{l}\text { No. } \\
(\%)\end{array}$ & No. $(\%)$ & No. $(\%)$ & $\begin{array}{l}\text { No. } \\
(\%)\end{array}$ & $\begin{array}{l}\text { No. } \\
(\%)\end{array}$ \\
\hline $\begin{array}{c}\text { Tractor } \\
\text { ploughing }\end{array}$ & 0 & $38(95)$ & 0 & $\begin{array}{c}2 \\
(5)\end{array}$ & $8(7.27)$ & 0 & $\begin{array}{c}90 \\
(81.81)\end{array}$ & 0 & $\begin{array}{c}12 \\
(10.90)\end{array}$ & 0 \\
\hline $\begin{array}{c}\text { Manual } \\
\text { ploughing }\end{array}$ & 0 & 0 & $\begin{array}{c}52 \\
(47.27)\end{array}$ & 0 & $42(38.18)$ & $\begin{array}{c}20 \\
(50)\end{array}$ & $16(14.54)$ & $\begin{array}{l}10 \\
(25)\end{array}$ & 0 & $\begin{array}{c}10 \\
(25)\end{array}$ \\
\hline Planting & $\begin{array}{c}108 \\
(98.18)\end{array}$ & 0 & $\begin{array}{c}2 \\
(1.81)\end{array}$ & 0 & $2(1.81)$ & 0 & 0 & $35(87.5)$ & 0 & $5(12.5)$ \\
\hline
\end{tabular}


Int.J.Curr.Microbiol.App.Sci (2020) 9(4): 1332-1339

\begin{tabular}{|c|c|c|c|c|c|c|c|c|c|c|}
\hline Weeding & $\begin{array}{c}98 \\
(89.09)\end{array}$ & 0 & $\begin{array}{c}4 \\
(3.64)\end{array}$ & 0 & $6(5.45)$ & 0 & $2(1.81)$ & $\begin{array}{c}30 \\
(75)\end{array}$ & 0 & $\begin{array}{c}10 \\
(25)\end{array}$ \\
\hline $\begin{array}{l}\text { Fertilizer } \\
\text { application }\end{array}$ & $60(54.54)$ & 0 & $\begin{array}{c}22 \\
(20)\end{array}$ & $\begin{array}{c}12 \\
(30)\end{array}$ & $2(1.81)$ & $\begin{array}{c}8 \\
(20)\end{array}$ & $26(23.64)$ & $\begin{array}{c}10 \\
(25)\end{array}$ & 0 & $\begin{array}{c}10 \\
(25)\end{array}$ \\
\hline $\begin{array}{l}\text { Pesticide } \\
\text { application }\end{array}$ & $\begin{array}{c}58 \\
(52.72)\end{array}$ & 0 & $\begin{array}{c}24 \\
(21.82)\end{array}$ & $\begin{array}{c}12 \\
(30)\end{array}$ & $2(1.81)$ & $\begin{array}{c}8 \\
(20)\end{array}$ & $\begin{array}{c}26 \\
(23.64)\end{array}$ & $\begin{array}{c}10 \\
(25)\end{array}$ & 0 & $\begin{array}{c}10 \\
(25)\end{array}$ \\
\hline Harvesting & $\begin{array}{c}66 \\
(60)\end{array}$ & 0 & $\begin{array}{c}16 \\
(14.55)\end{array}$ & $\begin{array}{c}12 \\
(30)\end{array}$ & $2(1.81)$ & $\begin{array}{c}8 \\
(20)\end{array}$ & $\begin{array}{c}26 \\
(23.64)\end{array}$ & $\begin{array}{c}10 \\
(25)\end{array}$ & 0 & $\begin{array}{c}10 \\
(25)\end{array}$ \\
\hline Threshing & 0 & 0 & $\begin{array}{c}20 \\
(18.18)\end{array}$ & $\begin{array}{c}12 \\
(30)\end{array}$ & $\begin{array}{c}40 \\
(36.36)\end{array}$ & $\begin{array}{c}8 \\
(20)\end{array}$ & $\begin{array}{c}50 \\
(45.45)\end{array}$ & $\begin{array}{c}20 \\
(50)\end{array}$ & 0 & 0 \\
\hline $\begin{array}{c}\text { Manual } \\
\text { production } \\
\text { transport }\end{array}$ & 0 & $\begin{array}{c}22 \\
(55)\end{array}$ & $\begin{array}{c}5 \\
(4.55)\end{array}$ & $\begin{array}{c}18 \\
(45)\end{array}$ & $\begin{array}{c}58 \\
(52.73)\end{array}$ & 0 & $\begin{array}{c}41 \\
(37.27)\end{array}$ & 0 & $\begin{array}{c}6 \\
(5.45)\end{array}$ & 0 \\
\hline $\begin{array}{c}\text { Production } \\
\text { storage }\end{array}$ & $\begin{array}{c}42 \\
(38.18)\end{array}$ & 0 & $\begin{array}{c}40 \\
(36.36)\end{array}$ & $\begin{array}{c}12 \\
(30)\end{array}$ & $2(1.81)$ & $\begin{array}{c}8 \\
(20)\end{array}$ & $\begin{array}{c}26 \\
(23.64)\end{array}$ & $\begin{array}{c}10 \\
(25)\end{array}$ & 0 & $\begin{array}{c}10 \\
(25)\end{array}$ \\
\hline $\begin{array}{c}\text { Production } \\
\text { market }\end{array}$ & 0 & 0 & $\begin{array}{c}12 \\
(10.91)\end{array}$ & $\begin{array}{c}12 \\
(30)\end{array}$ & $\begin{array}{c}28 \\
(25.45)\end{array}$ & $\begin{array}{c}8 \\
(20)\end{array}$ & $\begin{array}{c}66 \\
(60)\end{array}$ & $\begin{array}{c}10 \\
(25)\end{array}$ & $\begin{array}{c}4 \\
(3.64)\end{array}$ & $\begin{array}{c}10 \\
(25)\end{array}$ \\
\hline $\begin{array}{l}\text { Livestock } \\
\text { shade } \\
\text { construction }\end{array}$ & $\begin{array}{c}72 \\
(65.45)\end{array}$ & 0 & $\begin{array}{c}14 \\
(12.73)\end{array}$ & $\begin{array}{c}8 \\
(20)\end{array}$ & $\begin{array}{c}20 \\
(18.18)\end{array}$ & $\begin{array}{c}10 \\
(25)\end{array}$ & $4(3.64)$ & $\begin{array}{c}10 \\
(25)\end{array}$ & 0 & $\begin{array}{c}12 \\
(30)\end{array}$ \\
\hline $\begin{array}{l}\text { Livestock } \\
\text { feeding }\end{array}$ & $\begin{array}{c}78 \\
(70.91)\end{array}$ & 0 & $\begin{array}{c}11 \\
(10)\end{array}$ & $\begin{array}{c}2 \\
(5)\end{array}$ & $4(3.64)$ & $\begin{array}{c}11 \\
(27.5)\end{array}$ & $\begin{array}{c}17 \\
(15.45)\end{array}$ & $\begin{array}{c}12 \\
(30)\end{array}$ & 0 & $\begin{array}{c}14 \\
(35)\end{array}$ \\
\hline $\begin{array}{c}\text { Shade } \\
\text { cleaning }\end{array}$ & $\begin{array}{c}41 \\
(37.27)\end{array}$ & 0 & $\begin{array}{c}29 \\
(26.36)\end{array}$ & 0 & $\begin{array}{c}12 \\
(10.91)\end{array}$ & $\begin{array}{c}8 \\
(20)\end{array}$ & $\begin{array}{c}28 \\
(25.45)\end{array}$ & $\begin{array}{c}10 \\
(25)\end{array}$ & 0 & $\begin{array}{c}22 \\
(55)\end{array}$ \\
\hline $\begin{array}{c}\text { Dung } \\
\text { processing }\end{array}$ & $\begin{array}{c}78 \\
(70.91)\end{array}$ & 0 & $\begin{array}{c}22 \\
(20)\end{array}$ & 0 & $8(7.27)$ & $\begin{array}{c}13 \\
(32.5)\end{array}$ & $2(1.81)$ & $\begin{array}{c}13 \\
(32.5)\end{array}$ & 0 & $\begin{array}{c}14 \\
(35)\end{array}$ \\
\hline $\begin{array}{l}\text { Milking and } \\
\text { milk } \\
\text { processing }\end{array}$ & $\begin{array}{c}20 \\
(18.18)\end{array}$ & 0 & $\begin{array}{c}17 \\
(15.45)\end{array}$ & 0 & $\begin{array}{c}37 \\
(33.64)\end{array}$ & $\begin{array}{c}6 \\
(15)\end{array}$ & $\begin{array}{c}35 \\
(31.82)\end{array}$ & $\begin{array}{c}25 \\
(62.5)\end{array}$ & $\begin{array}{c}1 \\
(0.9)\end{array}$ & $\begin{array}{c}9 \\
(22.5)\end{array}$ \\
\hline $\begin{array}{l}\text { Livestock } \\
\text { selling }\end{array}$ & 0 & $\begin{array}{c}38 \\
(95)\end{array}$ & 0 & $\begin{array}{c}2 \\
(5)\end{array}$ & $8(7.27)$ & 0 & $\begin{array}{c}90 \\
(81.82)\end{array}$ & 0 & $\begin{array}{c}12 \\
(10.91)\end{array}$ & 0 \\
\hline Herding & 0 & 0 & $\begin{array}{c}69 \\
(62.73)\end{array}$ & 0 & $\begin{array}{c}36 \\
(32.72)\end{array}$ & $\begin{array}{c}8 \\
(20)\end{array}$ & $5(4.55)$ & $\begin{array}{c}25 \\
(62.5)\end{array}$ & 0 & $\begin{array}{c}7 \\
(17.5)\end{array}$ \\
\hline $\begin{array}{c}\text { Poultry/ } \\
\text { Goat } \\
\text { production }\end{array}$ & $\begin{array}{c}72 \\
(65.45)\end{array}$ & 0 & $\begin{array}{c}11 \\
(10)\end{array}$ & 0 & $\begin{array}{c}27 \\
(24.54)\end{array}$ & $\begin{array}{c}1 \\
(2.5)\end{array}$ & 0 & $\begin{array}{c}22 \\
(55)\end{array}$ & 0 & $\begin{array}{c}17 \\
(42.5)\end{array}$ \\
\hline
\end{tabular}

Source: Field Survey data, 2019-20 
Table.4 Time budget analysis for gender division of labour (hrs./day) in the main agricultural season

\begin{tabular}{|l|c|c|}
\hline \multicolumn{1}{|c|}{ Activities } & Male heads & Female heads \\
\hline $\begin{array}{l}\text { Cooking \& related works } \\
\text { childcare, sanitation) }\end{array}$ & 0.002 & 4.63 \\
\hline Fetching water & 0.01 & 0.91 \\
\hline Fire wood collection & 0.16 & 0.94 \\
\hline Kitchen gardening & 0.32 & 0.71 \\
\hline Poultry/livestock/goatery related works & 0.29 & 0.83 \\
\hline On farm work/ Hired labour & 8.12 & 2.67 \\
\hline Total & 8.862 & 10.69 \\
\hline
\end{tabular}

Source: Field Survey data, 2019-20

Table.5 Factors hindering female headed households' participation in agricultural extension service

\begin{tabular}{|l|c|c|}
\hline Constraints & Score & Rank order \\
\hline Low exposure & 610 & $\mathrm{I}$ \\
\hline Low reach of extension systems & 592 & $\mathrm{II}$ \\
\hline Less family labour & 460 & $\mathrm{III}$ \\
\hline Low education level & 412 & $\mathrm{IV}$ \\
\hline Fragmented land holdings & 333 & $\mathrm{~V}$ \\
\hline Lack of credit availability & 306 & $\mathrm{VI}$ \\
\hline Excess workload & 214 & $\mathrm{VII}$ \\
\hline
\end{tabular}

Source: Field Survey data, 2019-20

The study brings out starkly the contribution of women to agricultural food production and management of activities. The study also indicates the dominance of male farmers in provision of extension service. In the current century, it is important to provide genderresponsive training to extension workers in particular for better dissemination of information.

The initiative of ICAR in including genderresponsive training in all the training programmes is a noteworthy step in that direction. It should also be allowed by other developmental units at large. The access of women farmers to extension services must lead to concrete improvements for rural women themselves, as well as enhance the productivity of the agricultural sector and national food security through increasing marketed output. There is a need to collect region-wise data from the country at specific intervals along with proper integration in the developmental programmes so as to understand gender roles in agriculture and how they change over time and in response to new opportunities.

\section{References}

Elias, Asres, et al., Does Gender Division of Labour Matters for the Differences in Access to Agricultural Extension Services? A Case Study in North West Ethiopia. Journal of agricultural science 7.1 (2014): 138. 
ET contributors (2017). Retrieved from http://economictimes.indiatimes.com/a rticleshow/61721335.cms?utm_source $=$ contentofinterest\&utm_medium $=$ text \&utm_campaign=cppst on 4 December, 2017.

FAO (2011). The state of food and agriculture 2010-2011. Rome: Food and Agriculture Organization of the United Nations retrieved from http://www.fao.org/docrep/013/am307 e/am307e00.pdf on November 21,
2017.

Perraton, H., Jamison, D., and Orival, F. (1983). Mass media for agricultural extension in Malawi (p. 147-202). In Basic education and agricultural extension: Costs, effects and alternatives. Staff Working Paper No. 564. Washington, DC: World Bank.

Staudt, K. (1975). Women farmers and inequities in agricultural services. Rural Africana, 29, 81-93.

\section{How to cite this article:}

Mani Bhushan, Aditya Sinha, SaritaKumari and Dharmendra Debbarma. 2020. Gender Divide in Provision of Extension Services in Agriculture. Int.J.Curr.Microbiol.App.Sci. 9(04): 13321339. doi: https://doi.org/10.20546/ijcmas.2020.904.158 